\title{
Analisis Pengungkapan Faktor-Faktor Yang Mempengaruhi Penerapan Internet Financial Reporting (IFR) Sebagai Voluntary Disclosure Pada Tahun 2014-2018
}

\author{
Anita Dwi Oktaviani ${ }^{1}$ \\ anitadwio@yahoo.co.id \\ Hastutie Noor Andriati ${ }^{1}$ \\ Rudiawie Larasati ${ }^{1}$ \\ Jurusan Akuntansi, Fakultas Ekonomi dan Bisnis Universitas Cenderawasih
}

\begin{abstract}
This study aims to test and analyze empirically the influence of company size, profitability, leverage, outside ownership, and systematic risk on internet financial reporting, an empirical study of manufacturing companies listed on the Indonesia Stock Exchange from 2014 to 2018. In companies, the development of information technology, especially the internet very much used to facilitate various processes and activities of the company. The rapid use of the internet in the business world requires companies to use the internet for several company activities such as transactions, searching, or sharing information in hard-to-reach areas. This study uses a quantitative approach with the research population, namely companies included in the manufacturing sector listed on the Indonesia Stock Exchange in 2014, 2015, 2016, 2017, and 2018.

Data on financial reports and annual financial reports can be obtained through access to www.IDX.co.id. The population in this study were 123 manufacturing companies listed on the Indonesia Stock Exchange in the 2014-2018 period. The number of samples used in this study was 29 company samples. The analysis technique used in this research is multiple linear regression in order to obtain a comprehensive picture of the relationship between the independent and dependent variables.

Based on the results of this study, company size has no significant effect on internet financial reporting with a significant value of 0.550 , profitability has a significant effect on internet financial reporting with a significant value of 0.000 , leverage has a significant effect on internet financial reporting with a significant value of 0.001, outside ownership has a significant effect on internet financial reporting. internet financial reporting with a significant value of 0.034 and systematic risk has no significant effect on internet financial reporting with a significant value of 0.862.
\end{abstract}

Keywords: Size firm; Profitability; Leverage; Outside ownership; Systematic risk; Internet financial reporting

\begin{abstract}
Abstrak
Penelitian ini bertujuan untuk menguji dan menganalisis secar empiris adanya pengaruh ukuran perusahaan, profitabilitas, laverage, outside ownership dan resiko sistematik terhadap internet financial reporting studi empiris perusahaan manufaktur yang terdaftar di Bursa Efek Indonesia tahun 2014 sampai 2018. Pada perusahaan, perkembangan teknologi informasi khususnya internet sangat dimanfaatkan untuk mempermudah berbagai proses kegiatan dan aktivitas perusahaan. Pesatnya penggunaan internet dalam dunia bisnis menuntut perusahaan untuk menggunakan internet pada beberapa aktivitas perusahaan seperti transaksi, mencari atau berbagi informasi pada wilayah yang sulit dijangkau. Penelitian ini menggunakan pendekatan kuantitatif dengan populasi penelitiannya yaitu perusahaan-perusahaan yang termasuk dalam sektor manufaktur yang terdaftar di Bursa Efek Indonesia tahun 2014, 2015, 2016, 2017 dan 2018.

Data laporan keuangan dan laporan keuangan tahunan dapat diperoleh melalui akses ke www.idx.co.id. Populasi pada penelitian ini sebanyak 123 perusahaan manufaktur yang terdaftar di Bursa Efek Indonesia pada periode 2014-2018. Jumlah sampel yang digunakan pada penelitian ini sebayak 29 sampel perusahaan. Teknik analisa yang digunakan dalam penelitian ini adalah regresi linier berganda agar dapat memperoleh gambaran yang menyeluruh mengenai hubungan variabel independen dan variabel dependen.

Berdasarkan hasil penelitian ini ukuran perusahaan tidak bepengaruh signifikan terhadap internet
\end{abstract}


financial reporting dengan nilai signifikan sebesar 0,550 , profitabilitas berpengaruh signifikan terhadap internet financial reporting dengan nilai signifikan sebesar 0,000 , laverage berpengaruh signifikan terhadap internet financial reporting dengan nilai signifikan sebesar 0,001, outside ownership berpengaruh signifikan terhadap internet financial reporting dengan nilai signifikan sebesar 0,034 dan resiko sistematik tidak bepengaruh signifikan terhadap internet financial reporting dengan nilai signifikan sebesar 0,862 .

Kata Kunci : Ukuran perusahaan, Profitabilitas, Laverage, Outside ownership, Resiko sistematik, Internet financial reporting.

\section{Pendahuluan}

Laporan keuangan suatu perusahaan dapat dijadikan sebagai gambaran untuk menilai bagaimana kinerja suatu perusahaan. Bagi stakeholder atau para investor, laporan keuangan dapat dilihat sebagai alat untuk meyakinkan mereka dalam berinvestasi. Hal ini karena informasi dalam laporan keuangan dapat dijadikan sebagai analisis yang dapat menggambarkan perkembangan perusahaan. Selain untuk mengetahui kinerja perusahaan bagi investor, laporan keuangan juga dapat menggambarkan bagaimana suatu perusahaan berjalan. Untuk penyebarluasan informasi yang cepat dan dapat menjangkau berbagai wilayah, perusahaan memerlukan sarana dimana salah satu media yang digunakan perusahaan adalah internet.

Website merupakan halaman informasi yang berisi gambar, animasi, tulisan yang disusun secara terstruktur. Melalui internet berbagai informasi yang telah disediakan dengan menggunakan website dapat dengan mudah di akses. Maka setiap informasi akan lebih mudah dan cepat tersampaikan walaupun pemilik informasi tidak menginfokan dengan manual.

Sebuah website merupakan sebuah representasi virtual tentang suatu bisnis, berita, dan usaha. Dengan adanya kemajuan pada teknologi yang semakin modern, para pengguna internet menginginkan kemudahan dan keakuratan untuk segala informasi, maka dengan adanya website dapat membantu pelaku bisnis atau pelaku usaha untuk menawarkan jasa, usaha dan bisnis yang mereka jalankan, serta laporan keuangan suatu perusahaan juga dapat disajikan dalam sebuah website.

Dengan adanya penerapan IFR pada suatu entitas usaha yaitu adanya pengungkapan informasi pada keuangan perusahaan menggunakan website perusahaan melalui internet, hal ini menjadi pendukung internet sebagai sarana utama untuk pelaporan keuangan serta perpindahan periode paperbased reporting system menjadi paper-less reporting system (Hanifa \& Ab, 2005). Perubahan tersebut juga merupakan suatu langkah baik karena dapat memudahkan penggunanya serta dapat meminimalisir biaya yang dikeluarkan.

Penggunaan media internet untuk memberikan informasi telah berkembang pesat. Pengungkapan sukarela merupakan informasi perusahaan yang ditampilkan melalui website pada beberapa negara berkembang, seperti di Indonesia (Almilia, 2008) Menurut (Chariri, 2005) adanya perubahan dalam penyebaran informasi dikarenakan adanya juga perkembangan yang pesat dalam dunia internet. Penggunaan internet telah banyak diterapkan perusahaan sebagai alat komunikasi terkait penyediaan informasi pada penyebarluasan informasi keuangan. Perbedaan penelitian ini dengan penelitian sebelumnya yaitu terletak pada tahun 2014 sampai dengan 2018.

\section{Tinjauan Pustaka}

\subsection{Agency Theory}

Teori Agensi adalah suatu model kontraktual antara dua atau lebih orang (pihak) dimana salah satu pihak disebut agen dan pihak lain disebut prinsipal. Manajemen perusahaan merupakan agen dan pemegang saham merupakan prinsipal yang berkepentingan atas kepemilikannya terhadap perusahaan. Teori agensi menyatakan bahwa dalam asimetri informasi, manajemen dapat memilih keputusan yang memaksimalkan kepentingannya. Keputusan ini berbeda dengan keputusan yang dibutuhkan untuk memaksimalkan kepentingan bagi pemegang saham (Jensen and Meckling, 1976 dalam Marwati, 2016).

Pada dasarnya teori ini berupaya untuk mengatasi adanya perbedaan kepentingan yang terjadi di antara keduanya, salah satunya dengan menyediakan informasi akuntansi yang relevan sehingga dapat 
memaksimalkan keuntungan dengan mempertimbangankan kerugian yang mungkin timbul dan berdampak pada pihak lain (Marwati, 2016). Praktik IFR tidak dapat dipisahkan dari teori keagenan, dalam kerangka teori kegenan sendiri terdapat tiga macam jenis hubungan keagenan, yaitu hubungan keagenan antara pemilik dengan manajer, hubungan keagenan antara kreditur dengan manajer, dan hubungan keagenan antara pemerintah dengan manajer, lebih lanjut Lestari dan Chariri (2007) dalam kutipan Susanti (2017) menjelaskan bahwa agen atau manajer memiliki kecenderungan untuk melaporkan sesuatu dengan cara tertentu sesuai dengan jenis hubungannya, teori keagenan mengasumsikan bahwa agen menginginkan kompensasi yang besar atas kinerjanya dimana prestasi agen diukur berdasarkan kemampuannya memperbesar laba (Handoko, 2013) dan untuk memaksimalkan utilitas yang akan diperoleh maka agen akan berupaya untuk meyampaikan informasiinformasi kepada pengguna informasi dengan berbagai metode terbaik, salah satunya dengan menerapkan praktik IFR.

\subsection{Teori Sinyal (Signaling Theory)}

Signaling theory dapat digunakan untuk memprediksi kualitas pelaporan sukarela, yaitu dengan menggunakan media internet maka dapat digunakan untuk meningkatkan kualitas pelaporan keuangan. Informasi terkait dengan keadaan perusahaan serta memberikan sinyal pada pihak-pihak berkepentingan melalui website.

\subsection{Pengungkapan Wajib (Mandatory Disclosure)}

Yaitu pengungkapan minimum yang harus diungkapkan atau disyaratkan oleh standar akuntansi yang berlaku (kewajiban perusahaan).

\subsection{Pengungkapan Sukarela (Voluntary Disclosure)}

Bentuk pengungkapan sukarela adalah salah satu contoh praktek pengungkapan informasi keuangan dalam website perusahaan IFR (Internet Financial Reporting) (Reskino \& Sinaga, 2017). Pengungkapan ini berupa informasi yang dilakukan sukarela oleh perusahaan.

Menurut (Almilia, 2008) kategori pengungkapan sukarela adalah salah satu pengungkapan yang dilakukan oleh perusahaan melalui media website. Untuk menjelaskan pengungkapan sukarela terdapat beberapa teori yang dapat digunakan yaitu teori keagenan, dan signaling theory. Dengan meningkatkan pengungkapan, hasil dari beberapa penelitian bahwa masalah teori keagenan dapat dikurangi.

\subsection{Model Penelitian}

Berdasarkan uraian diatas, maka model penelitian dapat digambarkan sebagai berikut:

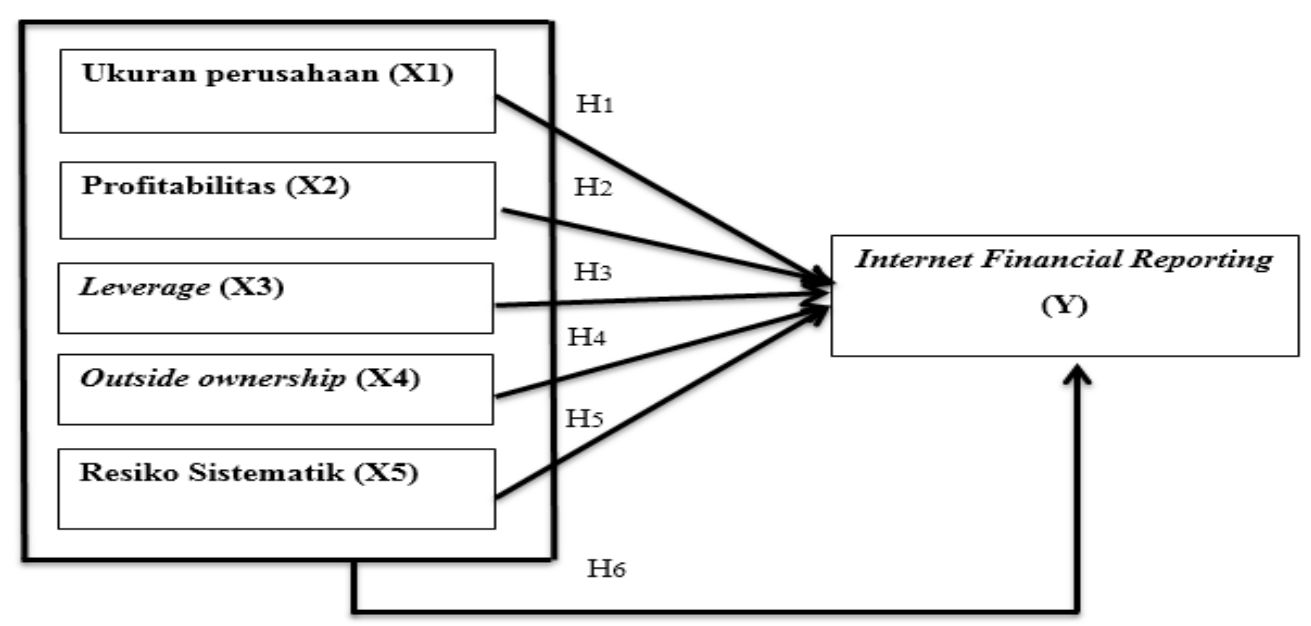

Gambar 1. Model Penelitian (Sumber : Penulis, 2020) 


\section{Metode Penelitian}

\subsection{Populasi dan Sampel}

Populasi digunakan untuk menyebutkan serumpun atau sekelompok objek yang menjadi masalah sasaran penelitian. Populasi dalam penelitian ini menggunakan perusahaan manufaktur dan laporan tahunan yang telah dipublikasikan pada tahun 2014-2018 yang terdaftar di Bursa Efek Indonesia (BEI) yaitu www.idx.co.id.

Sampel adalah suatu contoh yang diambil dari populasi. Sampel yang diambil adalah perusahaan manufaktur yang terdaftar di Bursa Efek Indonesia (BEI) periode penelitian tahun 2014-2018. Pada penelitian ini metode pengambilan sample yang digunakan adalah purposive sampling dengan kriteria sebagai berikut :

1. Perusahaan manufaktur yang terdaftar di Bursa Efek Indonesia tahun 2014-2018.

2. Perusahaan manufaktur yang memiliki laporan keuangan dan laporan tahunan yang lengkap 2014-2018.

3. Perusahaan manufaktur yang menyajikan laporan keuangan dalam mata uang rupiah.

\subsection{Definisi Operasional \\ Variabel Dependen}

IFR merupakan sarana untuk mengkomunikasikan sinyal positif perusahaan kepada publik, terutama investor. Internet financial Reporting dapat mempermudah perusahaan untuk menyampaikan informasi berupa laporan keuangan dan non keuangan kepada pengguna laporan tersebut dan investor. Terdapat 4 item pengungkapan Internet Financial Reporting (IFR) yang terdiri dari, Isi (Content), Ketepatan Waktu (Timeliness), Teknologi (Technology), Dukungan Pengguna (User Support).

IFR $=\left(\frac{\text { score }}{\text { Max }} \%\right.$ CONT $)+\left(\frac{\text { score }}{\text { Max }} \%\right.$ TIME $)+\left(\frac{\text { Score }}{\text { Max }} \%\right.$ TECH $)+\left(\frac{\text { Score }}{\text { Max }} \%\right.$ SUPP $)$

\section{Variabel Independen}

\section{a. Ukuran Perusahaan}

Ukuran Perusahaan adalah suatu skala dimana dapat diklasifikasikan besar kecil suatu perusahaan. Semakin besar ukuran perusahaan maka akan cendrung melakukan praktik Internet Financial Reporting (IFR) dalam penyebarluasan laporan keuangan atau non keuangan.

\section{Firm size $=$ LnTotal Assets}

\section{b. Profitabilitas}

Profitabilitas adalah rasio yang digunakan untuk menilai kemampuan perusahaan untuk memperoleh keuntungan, dimana jumlah yang berasal dari pengurangan harga pokok produksi, biaya lain dan kerugian dari penghasilan atau penghasilan operasi.

$$
\text { ROA }=\frac{\text { Laba bersih setelah pajak }}{\text { Total Assets }}
$$

\section{c. Leverage}

Leverage dapat di gambarkan sebagai hubungan antara utang perusahaan terhadap modal maupun aset. Rasio ini dapat menjelaskan seberapa jauh suatau perusahaan dibiayai oleh utang atau pihak luar dengan kemampuan perusahaan yang dibiayai oleh modal.

$$
\text { DER }=\frac{\text { Total Utang }}{\text { Modal }} \times 100 \%
$$

\section{d. Outside Ownership}

Besarnya outside ownership menunjukkan besarnya kepemilikan perusahaan oleh pihak luar. Perusahaan dengan outside ownership yang tinggi cenderung melakukan pengungkapan sukarela untuk mengurangi konflik keagenan yang timbul dari kepemilikan yang menyebar.

$$
\text { Outside Ownership }=\frac{\text { Jumlah Kepemilikan Saham Publik }}{\text { Total Saham }} \times 100 \%
$$


e. Resiko Sistematik

Resiko sistematik ini merupakan faktor eksternal yang tidak dapat dikendalikan oleh perusahaan. Resiko sistematik pada umumnya diukur menggunakan beta saham. Beta saham umumnya digunakan sebagai pengukur resiko sistematik, koefisien sensitivitas suatu saham pada pergerakan saham dapat ditunjukan oleh beta saham.

$$
R i \mathrm{t}=\alpha+\beta \cdot R M+\varepsilon i
$$

\subsection{Analisis Data}

\section{Statistik Deskriptif}

Statistik deskriptif adalah bentuk analisis data penelitian untuk menguji generalisasi hasil penelitian berdasarkan satu sample. Variable dalam penelitian ini di deskripsikan menggunakan statistik deskriptif. Frequency table digunakan sebagai alat analisis. Hal ini dikarenakan skala yang digunakan berupa skala nominal. Agar data yang telah dikumpulkan dalam jumlah yang sangat banyak dapat disajikan dalam bentuk yang jelas dan baik, maka dibuat Frequency table.

\section{Uji Asumsi Klasik}

Sebelum dapat dilakukan pengujian hipotesis atau regresi maka dialkukan terlebih dahulu uji asumsi klasik. Uji asumsi klasik dilakukan untuk mengetahui apakah hasil model estimasi regresi telah dipenuhi agar benar-benar besar dari penyimpangan yang cukup serius terhadap gejala distribusi yang normal. Pada penelitian ini uji asumsi klasik terdiri dari beberapa pengujian yaitu, uji normalitas, uji multikolonearitas, uji heterokedastistas dan uji autokorelasi.

\section{Model Regresi Berganda}

Metode analisis ini digunakan untuk menguji apakah variabel ukuran perusahaan yang diproxikan dengan nilai logaritma natural dari total penjualan, profitabilitas yang diukur dengan ROA, leverage yang diproxikan dengan rasio utang jangka panjang dengan total ekuitas, outside ownership yang diproxikan dengan membandingkan porsi jumlah saham yang dimiliki publik dengan saham yang dimiliki perusahaan dan diukur dalam bentuk prosentase kepemilikan publik, resiko sistematik yang diproxikan dengan beta saham, mempengaruhi pelaporan keuangan perusahaan di internet (IFR).

Model yang digunakan untuk menguji hipotesis sebagai berikut:

IFR $=a+\beta 1 S I Z E+\beta 2 P R O F+\beta 3 L V R+\beta 4 O W N+\beta 5 R I S+e$

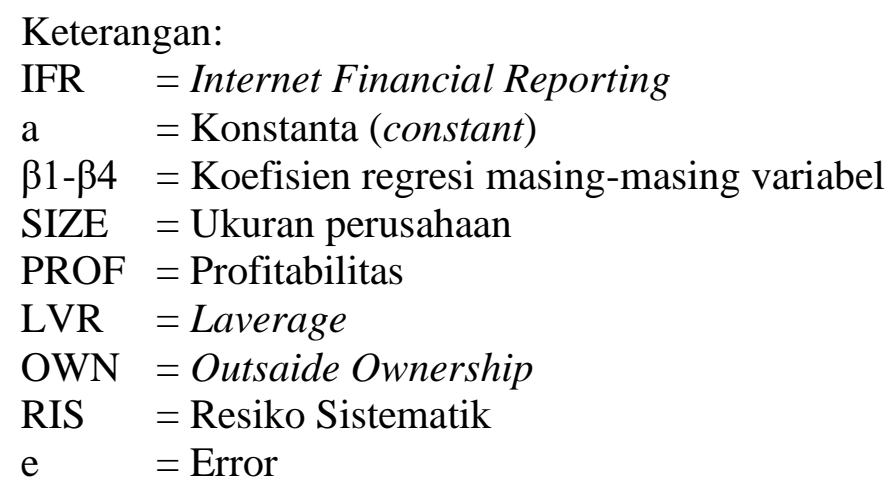

\section{Hasil Dan Pembahasan}

\section{Statistik Deskriptif}

Statistik deskriptif memberikan gambaran atau deskripsi suatu data yang dilihat dari nilai ratarata (mean), standar deviasi, varian, maksimum, minimum, sum, range, kurtosis, dan skewness (kemencengan distribusi) (Ghozali, 2016). Sampel yang digunakan dalam penelitian ini adalah 29 perusahaan yang terdaftar di Busa Efek Indonesia (BEI) berdasarkan hasil purposive sampling, di mana perusahaan-perusahaan tersebut memiliki laporan tahunan dan laporan keuangan (annual report) yang lengkap tahun 2014-2018 dan khususnya memiliki kelengkapan data yang digunakan sebagai variabel penelitian. 


\section{Hasil Pengujian Asumsi Klasik}

\section{a. Uji Normalitas}

Besarnya nilai Kolmogorov-Smirnov adalah 1,431 dan signifikansi pada 0,083 $(>0,05)$ yang menunjukkan nilai residual telah terdistribusi secara normal yang mendukung uji normalitas dengan grafik.

\section{b. Uji Multikolonearitas}

Berdasarkan hasil analisis, perhitungan nilai tolerance menunjukan tidak ada variabel independen yang memiliki nilai tolerance kurang dari 0,10 yang berarti tidak ada korelasi antar variabel independen. Serta berdasarkan perhitungan nilai variance inflation faktor (VIF) juga menunjukan hal yang sama, yakni tidak ada variabel independen dalam penelitian ini yang memiliki nilai variance inflation faktor (VIF) lebih dari 10. Dengan demikian, hasil analisis menunjukan tidak adanya masalah multikolonieritas.

\section{c. Uji Heterokedastistas}

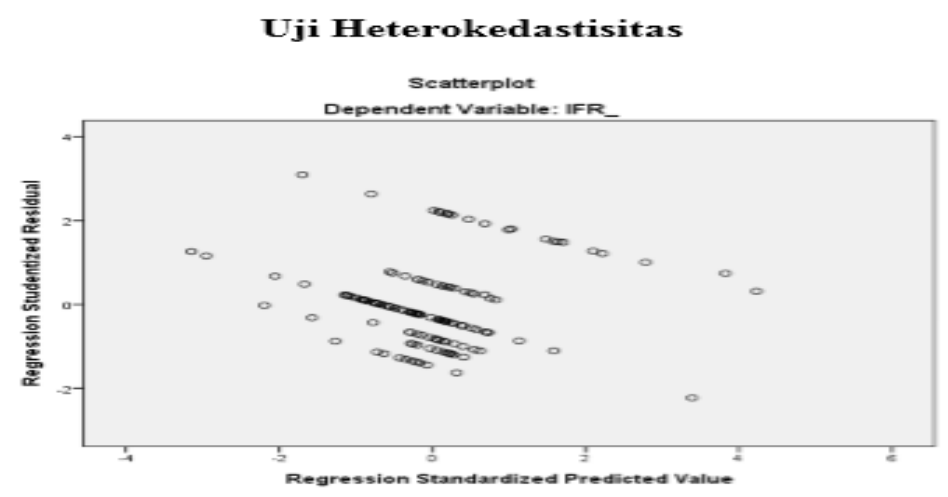

Gambar 2. Hasil uji Heterokedastisitas

Berdasarkan gambar diatas dapat disimpulkan, bahwa data yang digunakan dalam penelitian ini tidak mengandung heteroskedastisitas dimana data menyebar secara acak di bawah angka 0 pada sumbu $\mathrm{Y}$ atau tidak terjadi pengumpulan data.

\section{d. Uji Autokorelasi}

Diketahui nilai DW 1,937. Nilai ini akan dibandingkan dengan nilai tabel signifikansi 5\%. Jumlah sampel $\mathrm{N}=145$ dan jumlah variabel independen $5(\mathrm{~K}=5)$. Maka diperoleh nilai dU 1,800 dari tabel Durbin Watson.

Nilai DW 1,937 lebih besar dari batas atas (dU) yakni 1,800 dan kurang dari (4-dU) $4-1,800=2,200$. Sehingga dapat disimpulkan bahwa tidak terdapat autokorelasi.

\section{Analisis Regresi Linier Berganda}

Tabel 1. Analisis Regresi Linear Berganda

\begin{tabular}{|l|r|r|r|r|r|}
\hline \multirow{2}{*}{ Model } & \multicolumn{2}{|c|}{ Unstandardized Coefficients } & \multicolumn{1}{c|}{$\begin{array}{c}\text { Standardized } \\
\text { Coefficients }\end{array}$} & \multicolumn{1}{c|}{$\mathrm{t}$} & \multicolumn{1}{c|}{ Sig. } \\
\cline { 2 - 4 } & \multicolumn{1}{|c|}{$\mathrm{B}$} & Std. Error & \multicolumn{1}{|c|}{ Beta } & & \\
\hline \multirow{2}{*}{ (Constant) } & 136,857 & 25,011 & & 5,472 &, 000 \\
SIZE & 2,573 & 4,294 &, 046 &, 599 &, 550 \\
PROF & 63,230 & 17,564 &, 286 & 3,600 &, 000 \\
LVR & 32,638 & 10,069 &, 248 & 3,242 &, 001 \\
OWN & 1,310 &, 611 &, 166 & 2,144 &, 034 \\
RIS &, 985 & 5,658 &, 014 &, 174 &, 862 \\
\hline
\end{tabular}


$\mathrm{Y}=136,857+2,573 \mathrm{SIZE}+$ 63,230PROF + 32,638LVR + 1,310OWN +0,985RIS + e

Persamaan regresi diatas dapat menunjukkan bahwa koefisien yang bertanda positif adalah semua variabel bebas (independen) yaitu ukuran perusahaan (SIZE), profitabilitas (PROF), laverage (LVR), outside ownership (OWN) dan resiko sistematik (RIS). Hal ini berarti semua variabel bebas (indenpden) mempunyai pengaruh searah dengan internet financial reporting (IFR).

\section{Hasil Pengujian Hipotesis}

Hasil Uji Koefisien Determinasi

Tabel 2. Uji Koefisien Determinasi

\begin{tabular}{|c|c|c|c|c|c|}
\hline Model & $\mathrm{R}$ & R Square & $\begin{array}{l}\text { Adjusted R } \\
\text { Square }\end{array}$ & $\begin{array}{l}\text { Std. Error of the } \\
\text { Estimate }\end{array}$ & Durbin-Watson \\
\hline 1 &, $794^{\mathrm{a}}$ &, 330 &, 313 & 15,53933 & 1,937 \\
\hline
\end{tabular}

a. Predictors: (Constant), OWN, LVR, SIZE, RIS, PROF

b. Dependent Variable: IFR

Sumber: Data sekunder yang diolah, 2020

Berdasarkan hasil pada hasil uji koefisien determinasi hal ini menunjukkan bahwa SIZE, PROF, LVR, OWN dan RIS hanya mampu menjelaskan IFR sebesar 31,3\%. Sisanya sebesar $68,7 \%$ dipengaruhi oleh faktor-faktor lainnya yang tidak dimasukkan dalam model regresi pada penelitian ini.

Dari ke lima variabel independen yang dimasukkan kedalam model regresi, terlihat variabel profitabilitas, laverage, outside ownership yang signifikan, sementara size dan resiko sistematik tidak signifikan terhadap pengungkapan sukarela (IFR). Hal ini dapat dilihat dari nilai probabilitas dari profitabilitas sebesar 0,000 , laverage sebesar 0,001 dan outside ownership sebesar 0,034. Sementara size sebesar 0,550 dan resiko sistematik sebesar 0,862 .

\section{Pembahasan Hasil Hipotesis}

\section{Pengaruh Ukuran Perusahaan Terhadap Internet Financial Reporting}

Hipotesis yang diajukan dalam penelitian ini yaitu ukuran perusahaan tidak berpengaruh terhadap IFR. Ukuran perusahaan mencerminkan seberapa besar kekayaan yang dimiliki perusahaan yang dapat diketahui dari beberapa sisi seperti jumlah aktiva yang dimiliki, transaksi penjualan yang dilakukan, serta tingkat kapitalisasi pasar.

Berdasarkan pengujian yang dilakukan menunjukkan bahwa hipotesis tidak diterima. Perusahaan ukuran besar cenderung lebih transparan dalam menyajikan informasi keuangan kepada investor maupun stakeholders, sedangkan perusahaan ukuran kecil cenderung tidak transparan dalam menyajikan informasi keuangan dan lebih memilih untuk menyembunyikan informasi penting yang disebabkan adanya keunggulan bersaing (Almilia, 2008).

\section{Pengaruh Profitabilitas Terhadap Internet Financial Reporting}

Berdasarkan hasil pengujian diatas, variabel profitabilitas dengan menggunakan regresi linear berganda menunjukkan bahwa profitabilitas berpengaruh terhadap luas pengungkapan internet financial reporting. Hal ini menunjukkan bahwa profitabilitas mempengaruhi luas pengungkapan internet financial reporting. Dimana profitabilitas menjadi salah satu pertimbangan pengambilan keputusan investor dalam melakukan investasi, yaitu semakin besar profitabilitas maka semakin meningkat juga respon positif para investor terhadap pengambilan keputusan.

\section{Pengaruh Laverage Terhadap Internet Financial Reporting}

Hipotesis dalam penelitian ini yaitu leverage berpengaruh positif terhadap IFR. Leverage menunjukan seberapa besar ekuitas yang dimiliki perusahaan guna menjamin hutang yang didanai oleh 
kreditor. Menurut Sudarmadji dan Sularto, (2007) leverage merupakan pengukuran besarnya aktiva yang dibiayai dengan hutang dan hutang yang digunakan untuk membiayai aktiva berasal dari kreditor, bukan dari pemegang saham ataupun investor.

Berdasarkan pengujian yang dilakukan menunjukan bahwa hipotesis diterima. Semakin tinggi tingkat leverage menunjukan semakin besar tingkat pendanaan perusahaan yang dibiayai oleh hutang. Hal ini menyebabkan perusahaan akan melakukan pengungkapan informasi keuangan lebih luas kepada para pengguna laporan keuangan. Cara yang dapat digunakan untuk menyebarluaskan informasi keuangan adalah dengan menerapkan pelaporan keuangan berbasis internet (Keumala \& Muid, 2013).

Pernyataan tersebut sesuai dengan agency cost yang menyatakan bahwa perusahaan dengan tingkat leverage yang tinggi akan menyebabkan perusahaan memiliki kemampuan insentif untuk meningkatkan pengungkapan informasi perusahaan kepada stakeholders melalui website perusahaan. Hanny dan Chariri, (2007) menyatakan bahwa manajer dapat menerapkan praktif IFR untuk membantu dalam menyebarluaskan segala bentuk informasi positif yang dimiliki perusahaan kepada para kreditur dan stakeholders untuk tidak terfokus pada tingginya tingkat leverage perusahaan. Hal ini disebabkan Internet Financial Reporting (IFR) dapat memuat informasi perusahaan yang lebih luas dibandingkan melalui Paper Based Reporting.

Berdasarkan penelitian yang dilakukan sebelumnya terkait leverage, Hanny dan Chariri (2007) dengan hasil leverage berpengaruh positif terhadap IFR sesuai dengan penelitian Andriyani dan Mudjiyanti (2017) dengan hasil leverage berpengaruh positif terhadap IFR. Penelitian yang dilakukan Sofiana (2010) dengan hasil tingkat leverage berpengaruh positif terhadap pengungkapan IFR serta sejalan dengan penelitian.

\section{Pengaruh Outside Ownership Terhadap Internet Financial Reporting}

Variabel kepemilikan saham oleh publik memiliki nilai signifikansi sebesar 0,141, dimana nilai signifikansi lebih kecil dari tingkat signifikansi $0,05(0,034<0,05)$. Dengan demikian dapat disimpulkan bahwa hipotesis diterima. Alasan mendasar dari diterimanya hipotesis dalam penelitian ini karena kepemilikan saham yang kepemilikannya dibawah 5\% dan sifatnya adalah untuk diperjual belikan dan bukan untuk pengendalian manajemen. Hal ini menjadi pertimbangan manajemen perusahaan dalam melakukan penyebarluasan informasi mengenai laporan keuangan dalam website pribadi perusahaan.

\section{Pengaruh Resiko Sistematik Terhadap Internet Financial Reporting}

Hasil penelitian yang telah dilakukan menunjukan nilai signifikan resiko sistematik sebesar 0,862 , nilai tersebut lebih besar dari nilai a 0,05 maka hasil tersebut dapat diperoleh kesimpulan bahwa variabel risiko sistematik tidak berpengaruh signifikan terhadap Internet Financial Reporting yang menunjukkan bahwa tidak adanya pengaruh risiko sitematik terhadap kebijakan perusahaan untuk melakukan Interent Financial Reporting.

Marston dan Polei (2004) mengemukakan bahwa semakin tinggi resiko, maka manajer cenderung mengambil tindakan penyelamatan ketika membuat kebijakan, perusahaan-perusahaan yang memiliki resiko tinggi hanya memiliki sedikit dorongan untuk mengungkapkan informasi dalam website mereka. Penelitian ini sejalan dengan penelitian yang dilakukan oleh (Dul, 2013) yang menyatakan bahwa risiko sistematik tidak mempengaruhi perusahaan untuk melakukan IFR. Penelitian yang dilakukan (Rizki \& Ikhsan, 2018) dengan hasil resiko sistematik tidak berpengaruh terhadap pengungkapan IFR serta sejalan dengan penelitian.

\section{Pengaruh Ukuran Perusahaan, Profitabilitas, Laverage, Outside Ownership dan Resiko Sistematik Terhadap Internet Financial Reporting}

Hasil pengujian statistik $\mathrm{F}$ di atas menunjukan bahwa nilai signifikan 0.000 yang berarti pengujian tersebut di atas dengan menggunakan variabel independen (ukuran perusahaan, profitabilitas, laverage, outside ownership, resiko sistematik) secara simultan mempengaruhi variabel dependen (pengungkapan sukarela).

Hasil penelitian ini berbeda dengan penelitian yang dilakukan oleh (Dul, 2013) yang menyebutkan 
bahwa ukuran perusahaan, profitabilitas, laverage, outside ownership dan resiko sistematik secara simultan tidak berpengaruh terhadap IFR.

\section{Penutup}

\subsection{Kesimpulan}

1. Hasil uji menunjukkan bahwa ukuran perusahaan tidak berpengaruh terhadap tingkat pengungkapan IFR. Hal ini berarti ukuran perusahaan memiliki peranan yang tidak besar dalam pengungkapan IFR yang dilakukan oleh suatu perusahaan. Perusahaan cenderung tidak transparan dalam menyajikan informasi keuangan dan lebih memilih untuk menyembunyikan informasi penting yang disebabkan adanya keunggulan bersaing.

2. Hasil uji menunjukkan bahwa profitabilitas berpengaruh terhadap tingkat pengungkapan IFR. Hal ini menunjukkan bahwa profitabilitas mempengaruhi luas pengungkapan internet financial reporting. Dimana profitabilitas menjadi salah satu pertimbangan pengambilan keputusan investor.

3. Hasil uji menunjukkan bahwa laverage berpengaruh terhadap tingkat pengungkapan IFR. Dimana semakin tinggi tingkat leverage menunjukan semakin besar tingkat pendanaan perusahaan yang dibiayai oleh hutang. Hal ini menyebabkan perusahaan akan melakukan pengungkapan informasi keuangan lebih luas kepada para pengguna laporan keuangan. Cara yang dapat digunakan untuk menyebarluaskan informasi keuangan adalah dengan menerapkan pelaporan keuangan berbasis internet.

4. Hasil uji menunjukkan bahwa outside ownership berpengaruh terhadap tingkat pengungkapan IFR. Dimana kepemilikan saham yang kepemilikannya dibawah 5\% dan sifatnya adalah untuk diperjual belikan dan bukan untuk pengendalian manajemen.

5. Hasil uji menunjukkan bahwa resiko sistematik tidak berpengaruh terhadap tingkat pengungkapan IFR. Dimana tidak adanya pengaruh risiko sitematik terhadap kebijakan perusahaan untuk melakukan Interent Financial Reporting.

6. Hasil uji menunjukkan bahwa ukuran perusahaan, profitabilitas, laverage, outside ownership, resiko sistematik berpengaruh secara simultan terhadap tingkat pengungkapan IFR.

\subsection{Keterbatasan Penelitian}

1. Penelitian ini dilakukan hanya pada perusahaan manufaktur, sehingga pada hasil penelitian tidak menggambarkan keseluruhan perusahaan yang terdaftar di Bursa Efek Indonesia (BEI).

2. Variabel yang digunakkan dalam penelitian ini masih sangat terbatas untuk menjelaskan IFR, yaitu haya sebasar $31,3 \%$. Hal ini menunjukkan masih ada variabel lain yang perlu diindentifikasi untuk menjelaskan koefisien respon laba.

\subsection{Saran}

1. Bagi penelitian selanjutnya, disarankan agar menggunakan objek sampel perusahaan yang lebih luas dikarenakan setiap sektor ataupun industri perusahaan memiliki karakteristik yang berbedabeda. Variabel lain yang mungkin akan dapat mempengaruhi pengungkapan IFR yaitu jenis industri, reputasi auditor, internasionalisasi dan efisiensi.

2. Bagi investor dan calon investor, hendaknya juga menyadari arti penting dalam publikasi laporan keuangan dan kualitas dalam pembuatan laporan tersebut agar tidak salah untuk pengambilan keputusan.

3. Bagi perusahaan, hendaknya perusahaan harus menyadari pentingnya arti publikasi laporan keuangan. Karena informasi terhadap laporan keuangan sangat dibutuhkan oleh para investor dalam pengambilan keputusan.

\section{Daftar Pustaka}

Almilia, L. S. (2008). Faktor-Faktor Yang Memengaruhi Pengungkapan Sukarela Internet Financial and Sustainability Reporting. 17(1).

Andriyani, \& Mudjiyanti. (2017). Pengaruh Tingkat Profitabilitas, Leverage, Jumlah Dewan 
Komisaris Independen dan Kepemilikan Institusional terhadap Pengungkapan Internet Financial Reporting (IFR) Di Bursa Efek Indonesia.

Brigham, E. F., \& Houston, J. F. (2001). Manajemen Keuangan. (Jakarta : Erlangga).

Chariri, H. S. L. A. (2005). Analisis faktor-faktor yang mempengaruhi pelaporan keuangan melalui internet. Jurnal Akuntansi, 0-27. https://doi.org/10.1007/s13668-014-0115-1

Dewi R, A., Topowijono, \& Sulasmiyati, S. (2015). Pengaruh Ukuran Perusahaan, Profitabilitas, Struktur Modal, dan Keputusan Investasi terhadap Nilai Perusahaan sektor Properti, Real Estate, dan Building Construction di BEI Periode 2010-2013. Jurnal Administrasi Bisnis, 23, (2).

Dul, N. N. K. (2013). Analisis Faktor-Faktor Yang Mempengaruhi Pelaporan Keuangan Perusahaan Melalui Website Perusahaan. Analisis Faktor-Faktor Yang Mempengaruhi Pelaporan Keuangan Perusahaan Melalui Website Perusahaan, 2, 645-654.

Gat, F. (2015). Analisis Faktor-Faktor Yang Mempengaruhi Pelaporan Keuangan Melalui Internet (IFR) Pada Perusahaan Manufaktur Yang Terdaftar Di BEI. 8.

Ghozali, I. (2016). Aplikasi Analisis Multivariate dengan Program IBM SPSS.

Handayani, E. (2018). Internet Financial Reporting: Studi Komparasi Perusahaan Manufaktur Yang Terdaftar Di Bursa Efek Indonesia Dan Bursa Efek Malaysia. Journal of Chemical Information and Modeling, 53(9), 1689-1699. https://doi.org/10.1017/CBO9781107415324.004

Handoko, M. (2013). Anteseden dan Konsekuensi Tingkat Pengungkapan Informasi Keuangan Berbasis Internet. 1-15.

Hanifa, M. H., \& Ab, H. (2005). THE DETERMINANTS OF VOLUNTARY DISCLOSURES IN MALAYSIA : THE CASE OF INTERNET FINANCIAL. 2(1), 22-42.

Hanny, \& Chariri. (2007). Pelaporan Keuangan Melalui Internet (Internet Financial Reporting) dalam Website Perusahaan.

Harahap. (2013). Analisis Kritis Atas Laporan Keuangan. (Jakarta: PT Raja Grafindo Persada).

Hartoyo, \& Weko, A. K. (2014). Faktor-Faktor yang Mempengaruhi Struktur Modal Perusahaan Tekstil dan Garmen DI BEI. Accounting Analysis Journal., 3, 247-254.

Husnan, \& Suad. (2001). Dasar-Dasar Teori Portofolio dan Analisis Sekuritas. (Yogyakarta: Unit Penerbit dan Percetakan AMP YKPN).

Jensen, \& Meckling. (1976). The Theory of The Firm: Manajerial Behaviour, Agency Cost, and Ownership Structure. Journal of Financial and Economics, 3, 305-360.

Jogiyanto, H. M. (2008). Analisis dan Desain Sistem Informasi : Pendekatan Terstruktur Teori dan Praktek Aplikasi Bisnis. (Yogyakarta).

Kasmir. (2014). Analisis Laporan Keuangan. Edisi Pertama, Cetakan Ketujuh. Jakarta: PT. Rajagrafindo Persada.

Keumala, \& Muid. (2013). Keuangan Perusahaan Melalui Website Perusahaa.

Marston, C., \& Polei, A. (2004). Corporate reporting on the Internet by German companies. International Journal of Accounting Information Systems. 285- 311.

Marwati, S. (2016). Analisis Faktor-Faktor Yang Mempengaruhi Pelaporan Keuangan Perusahaan Di Internet (INTERNET FINANCIAL REPORTING). Skripsi, 23(45), 5-24.

Martalina, \& Lifessy. (2011). Pengaruh Profitabilitas dan Ukuran Perusahaan Terhadap Nilai PerusahaanDengan Struktur Modal Sebagai Variabel Intervening. Skripsi Akuntansi Fakultas Ekonomi Universitas Negeri Padang.

Munawir. (2004). Analisis Laporan Keuangan. Penerbit Liberty. Yogyakarta.

Reskino, \& Sinaga, N. N. J. (2017). Kajian Empiris Internet Financial Reporting Dan Praktek Pengungkapan. Media Riset Akuntansi, Auditing Dan Informasi, 16(2), 161. https://doi.org/10.25105/mraai.v16i2.1643

Riyanto, B. (2008). Dasar-dasar Pembelanjaan Perusahaan. Yogyakarta: Penerbit GPFE.

Rizki, F., \& Ikhsan, A. E. (2018). Pengaruh Rasio Aktivitas , Risiko Sistemati , dan Tingkat Kepemilikan Saham Terhadap Internet Financial Reporting ( Studi Pada Perusahaan Manufaktur Yang Terdaftar Di Bursa Efek Indonesia Periode 2011-2015 ). Jurnal Ilmiah Mahasiswa Ekonomi Akuntansi, 3(3), 443-458.

Rizqiah, R. N., \& Lubis, A. T. (2019). Penerapan Internet Financial Reporting (IFR) Pada Bank Umum Syariah Di Indonesia. Jurnal Akuntansi Dan Keuangan Islam, 5(1), 63-81. 
https://doi.org/10.35836/jakis.v5i1.14

Rohayati, S., \& Fernos, J. (2009). Siti Rohayati, Jhon Fernos. Profitabilitas, Analisis Pt, Pada, 1-7.

Rumiati. (2011). Analisis Faktor-Faktor yang Mempengaruhi Dividend Payout Ratio Pada Perusahaan manufaktur yang Listed di BEI Tahun 2006-2009.

Sartono, A. (2010). Menejemen Keuangan Teori dan Aplikasi. Edisi 4. Yogjakarta: BPFE.

Sofiana. (2010). Analisis Pengaruh Karakteristik Perusahaan terhadap Kelengkapan Pengungkapan dalam Laporan Tahunan Perusahaan Manufaktur yang Terdaftar di BEI.

Sudarmadji, \& Sularto. (2007). Pengaruh Ukuran Perusahaan, Profitabilitas Leverage, dan Tipe Kepemilikan Perusahaan Terhadap Luas Voluntary Disclosure Laporan Keuangan Tahunan.

Supomo, B., \& Indriantoro, N. (2002). Metodologi Penelitian Bisnis.

Susanti. (2017). Analisis Faktor-Faktor Yang Mempengaruhi Pelaporan Keuangan Melalui Internet Dengan Kinerja Keuangan Sebagai Variabel Moderasi. Retrieved from http://repository.umy.ac.id/bitstream/handle/123456789/19943/6.-BAB2.pdf? sequence $=5 \&$ is Allowed $=\mathrm{y}$

Syamsuddin, L. (2009). Manajemen Keuangan Perusahaan: Konsep Aplikasi dalam: Perencanaan, Pengawasan, dan Pengambilan Keputusan.

Supomo, B., \& Indriantoro, N. (2002). Metodologi Penelitian Bisnis. Cetakan Kedua, Yogyakara; Penerbit BFEE UGM.

Susanti. (2017). Analisis Faktor-Faktor Yang Mempengaruhi Pelaporan Keuangan Melalui Internet Dengan Kinerja Keuangan Sebagai Variabel Moderasi. Retrieved from http://repository.umy.ac.id/bitstream/handle/123456789/19943/6.-BAB2.pdf? sequence $=5 \&$ is Allowed $=\mathrm{y}$

Syamsuddin, L. (2009). Manajemen Keuangan Perusahaan: Konsep Aplikasi dalam: Perencanaan, Pengawasan, dan Pengambilan Keputusan. 